\title{
J-Synch protocol associated with estrus detection in beef heifers and non-lactating cows
}

\author{
[Protocolo J-Synch associado com detecção de estro em novilhas e vacas de corte não lactantes]
}

\section{"Review/Revisão"}

\author{
Bruna Mion $^{1 *}$, Ramiro Martins Bonotto ${ }^{2}$, Caroline Oliveira Farias ${ }^{1}$, Fernanda Souza Rosa ${ }^{2}$, \\ Jorgea Pradiee ${ }^{1}$, Monique Tomazele Rovani ${ }^{3}$, Lígia Margareth Cantarelli Pegoraro ${ }^{4}$, \\ Ana Lúcia Martins Bonotto ${ }^{5}$, Luiz Francisco Machado Pfeifer ${ }^{6}$, Augusto Schneider ${ }^{7}$
}

\author{
${ }^{1}$ Programa de Pós-Graduação em Veterinária, Universidade Federal de Pelotas, Campus Capão do Leão-RS, Brazil. \\ ${ }^{2}$ FAI Faculdades de Itapiranga, Itapiranga, SC, Brazil. \\ ${ }^{3}$ Instituto Federal Farroupilha, Frederico Westphalen, RS, Brazil. \\ ${ }^{4}$ Laboratório de Reprodução Animal, EMBRAPA Clima Temperado, Pelotas, RS, Brazil. \\ ${ }^{5}$ Central ABN Agropecuária, Santiago, RS, Brazil. \\ ${ }^{6}$ EMBRAPA Rondônia, Porto Velho, RO, Brazil. \\ ${ }^{7}$ Faculdade de Nutrição, Universidade Federal de Pelotas, Pelotas, RS, Brazil. \\ *Autor para correspondência/Corresponding author: E-mail: brunamion.vet@gmail.com
}

\begin{abstract}
The aim of this study was to compare the J-Synch and conventional protocols associated with estrus detection in beef heifers and to compare pregnancy rate between non-lactating cows displaying estrus or not during the J-Synch protocol. In Experiment 1, heifers were subjected to timed artificial insemination (AI) in a conventional protocol with ECP $(n=147)$ or J-Synch protocol plus eCG $(n=149)$. The AI occurred 12 hours after estrus expression; or 48 (Conventional protocol) and 72 hours (J-Synch protocol) after device removal for animals not displaying estrus. The J-Synch group received $10 \mu \mathrm{g}$ of GnRH at AI. In Experiment 2, the JSynch was performed ( $\mathrm{n}=116 \mathrm{cows}$ ), but without $\mathrm{eCG}$ injection, and estrus was monitored. Pregnancy rate was not different between protocols in Experiment 1 (Conventional: 50.68\%; J-Synch: 60.4\%). Heifers that displayed estrus had higher pregnancy rate only in the conventional protocol. In Experiment 2, pregnancy rate was not different between cows that displayed estrus or not. Therefore, performing AI earlier according to estrus expression increases pregnancy rate in conventional protocol, however it does not increase pregnancy rate in the J-Synch protocol.
\end{abstract}

Keywords: early artificial insemination; cattle; estrus behavior; GnRH-based protocol.

\section{Resumo}

Os objetivos desse estudo foram comparar o protocolo J-Synch e o protocolo convencional associados com detecção de estro em novilhas de corte e comparar a taxa de prenhez entre vacas não lactantes que demonstraram ou não estro após o protocolo J-Synch. No experimento 1, as novilhas foram submetidas à inseminação artificial (IA) em tempo fixo em um protocolo convencional com ECP $(n=147)$ ou através do protocolo J-Synch com eCG ( $\mathrm{n}=149)$. A IA ocorreu 24 horas após o estro; ou 48 (Convencional) e 72 horas (J-Synch) após a remoção do dispositivo naqueles animais que não demonstraram estro. O grupo J-Synch recebeu $10 \mu \mathrm{g}$ de GnRH no momento da IA. No experimento 2, foi aplicado o protocolo J-Synch (n=116 vacas) sem administração de eCG e o estro foi monitorado. No Experimento 1, a taxa de prenhez não foi diferente entre os protocolos (convencional: 50,68\%; J-Synch: 60,4\%). Novilhas que demonstraram estro tiveram maior taxa de prenhez apenas no protocolo convencional. No Experimento 2, a taxa de prenhez não foi diferente entre as vacas que demonstraram ou não estro. Assim, antecipar o momento da IA de acordo com o estro aumenta a taxa de prenhez no protocolo convencional, contudo não aumenta a taxa de prenhez no protocolo JSynch.

Palavras-chave: antecipação da inseminação artificial; bovinos; comportamento estral; protocolos baseados em GnRH. 


\section{Introduction}

Estrous cycle synchronization programs have been used worldwide to increase reproductive efficiency of beef cattle (Sa Filho et al., 2010; Pereira et al., 2014). Fixed-time artificial insemination (FTAI) allows an increase in the number of cows inseminated without estrous detection (Sa Filho et al., 2011a), facilitating the use of artificial insemination (AI) (Cavalieri et al., 2004) and minimizing time and labor costs (Dadarwal et al., 2013). The success of FTAI programs depends on the manipulation of several physiological processes, such as the recruitment of a new follicular wave, follicular dominance (Cerri et al., 2009) and moment of ovulation (Dadarwal et al., 2013). For this purpose, many FTAI protocols have been developed and used in commercial reproductive management programs (Sa Filho et al., 2010). In South America, protocols usually start with the insertion of a progesterone intravaginal device and the administration of estradiol benzoate (EB) (Bó et al., 1994). The treatment length with progesterone varies between 5 and 9 days, and the administration of a luteolytic dose of prostaglandin F2 $\alpha$ (PGF) is performed at device withdrawal. After that, estradiol, LH, or GnRH is administered around 24 and 72 hours after PGF to induce ovulation (Mapletoft et al., 2003) and the AI is performed 48-60 hours after progesterone device withdrawal (Sa Filho et al., 2010).

The length of proestrus can affect the results of an FTAI protocol (Bridges et al., 2010). A shortlength proestrus reduces follicular growth, resulting in lower serum estradiol concentration (Bridges et al., 2008; Bridges et al., 2010) and lower diameter of the ovulatory follicle, which results in a small corpus luteum, adversely affecting fertility (Dadarwal et al., 2013). Some studies have been performed to evaluate a protocol aiming to extend the proestrus length, named JSynch (de la Mata e Bó, 2012). The J-Synch protocol has a similar pregnancy rate to the conventional 5 days CO-Synch protocol (de la Mata e Bó, 2012). The J-Synch protocol promotes a proestrus longer by 28 hours (de la Mata et al., 2015) when compared to the conventional estradiol cypionate (ECP) protocol. Hastening AI according to estrus detection in the J-Synch protocol resulted in a tendency to increase pregnancy rate compared to the conventional protocol with ECP (de la Mata et al., 2015). Additionally, the administration of equine chorionic gonadotropin $(\mathrm{eCG})$ at the time of progesterone device withdrawal resulted in a higher pregnancy rate in the J-Synch protocol (Menchaca et al., 2015).

Despite this information, there are still few studies evaluating the J-Synch protocol, most studies available were performed with heifers, and there are no reports of its efficiency in beef cows. Additionally, there are no reports of association between estrus detection and eCG administration in J-Synch protocol for beef heifers. Therefore, the aims of this study were: 1) to compare the J-Synch and conventional protocols associated with estrus detection in beef heifers; and 2) to compare pregnancy rate between non-lactating cows displaying estrus or not during the J-Synch protocol.

\section{Material and Methods}

The experiments were performed at two commercial farms in southern Brazil. Experiment 1 was conducted to compare J-Synch and conventional protocols associated with estrus detection in beef heifers; and Experiment 2 was performed to compare pregnancy rate between non-lactating cows that displayed estrus or not during the J-Synch protocol.

\section{Experiment 1}

Experiment 1 was performed with 296 Braford heifers (Bos taurus x Bos indicus), with body condition score between 3 and 3.5 (scale from 1 to 5) (Houghton et al., 1990), 22 months of age, maintained on pasture (Avena sativa) in a commercial beef farm located in the state of Rio Grande do Sul, Brazil. All heifers were evaluated via ultrasonography (Mindray, 2200 vet, $6.0 \mathrm{MHz}$ transductor) and those with reproductive disorders were excluded from the study. The heifers were randomly allocated into one of two synchronization protocols: Conventional or J-Synch (Figure 1).

Heifers allocated in the conventional protocol $(n=147)$ received an intravaginal device (previously used for 8 days) with $1 \mathrm{~g}$ of progesterone (Sincrogest ${ }^{\circledR}$, Ouro Fino, Cravinhos, SP, Brazil) and $2 \mathrm{mg}$ of EB (Sincrodiol ${ }^{\circledR}$, Ouro Fino, Cravinhos, SP, Brazil). The day when the device was inserted was considered Day 0. On Day 7, heifers received $500 \mu \mathrm{g}$ of cloprostenol (Sincrocio ${ }^{\circledR}$, Ouro Fino, Cravinhos, SP, Brazil). On Day 9, the device was removed, and heifers 
received $1 \mathrm{mg}$ of ECP (SincroCP ${ }^{\circledR}$, Ouro Fino, Cravinhos, SP, Brazil) and 250 IU eCG (SincroECG ${ }^{\circledR}$, Ouro Fino, Cravinhos, SP, Brazil). On day 10 , three trained professionals performed estrus detection through visual observation for one hour. Heifers were considered in estrus when they were observed to stand after mounting. The heifers detected to be in estrus were inseminated 12 hours later. Those where estrus was not identified were inseminated 48 hours after progesterone device removal. Heifers from the J-Synch group $(n=149)$ also received an intravaginal device (previously used for 8 days) with $1 \mathrm{~g}$ of progesterone (Sincrogest $^{\circledR}$ ) and $2 \mathrm{mg}$ of EB (Sincrodiol $^{\circledR}$ ). On Day 6, the device was removed and heifers received $500 \mu \mathrm{g}$ of cloprostenol $\left(\right.$ Sincrocio $\left.^{\circledR}\right)$ and $250 \mathrm{IU}$ eCG $\left(\right.$ SincroECG $\left.^{\circledR}\right)$. On day 8 , three trained professionals performed estrus detection through visual observation for one hour. AI was performed 12 hours after estrus demonstration, or 72 hours after progesterone device removal for those not in estrus. At AI, all heifers received $10 \mu \mathrm{g}$ of a GnRH analogue (Sincroforte ${ }^{\circledR}$, Ouro Fino, Cravinhos, SP, Brazil).

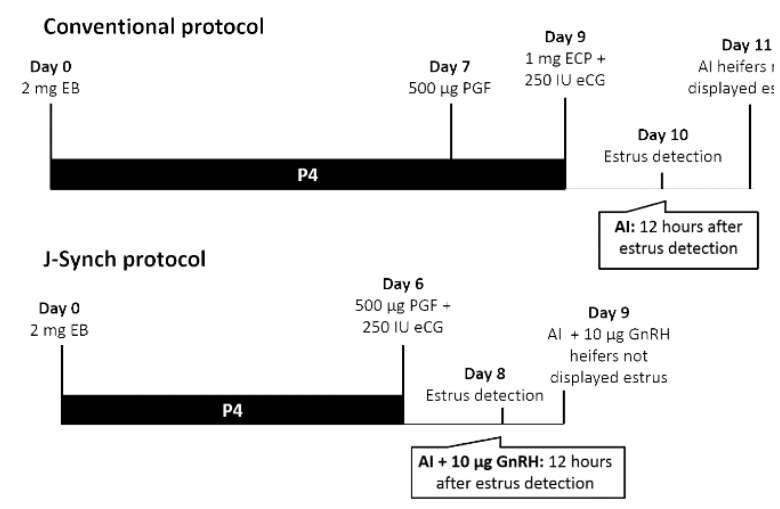

Figure 1. Experimental design used for heifers treated with conventional and J-Synch protocol in Experiment 1. EB: estradiol benzoate; P4: progesterone; PGF: prostaglandin $\mathrm{F} 2 \alpha$; ECP: estradiol cypionate; eCG: equine chorionic gonadotropin; AI: artificial insemination; GnRH: gonadotropin-releasing hormone.

The AI was performed by only one technician and commercial doses from five Braford sires with known fertility were used. The pregnancy diagnosis was performed 30 days after AI, through transrectal ultrasonography (Mindray, 2200 vet, $6.0 \mathrm{MHz}$ transductor).

\section{Experiment 2}

Experiment 2 was performed with 116 Aberdeen Angus (Bos taurus) multiparous nonlactating cows, with body condition score between
3 and 3.5 (scale from 1 to 5, Houghton et al., 1990), maintained on native pasture (Paspalum notatum, Cynodon dactylon, among others) from Southern Brazil, in a commercial beef farm located in the state of Rio Grande do Sul, Brazil.

Cows were assigned to the J-Synch synchronization protocol similar to the one described for heifers in the J-Synch group in Experiment 1. However, cows received a new intravaginal progesterone device $\left(\right.$ Sincrogest ${ }^{\circledR}$ ), and administration of eCG was not performed.

On day 8, three trained professionals performed estrus detection through visual observation for one hour. Cows were considered in estrus when they were observed to stand after mounting. AI was performed 12 hours after estrus was observed, or 72 hours after progesterone device removal for those not in estrus. The AI was performed by only one technician and commercial doses from four Aberdeen Angus sires with known fertility were used. The pregnancy diagnosis was performed as described for Experiment 1.

\section{Statistical analysis}

The results were analyzed using GraphPad ${ }^{\circledR}$ 6.01 (GraphPad software, Inc., CA, USA). The comparison of estrus demonstration and pregnancy rate in the different groups (J-Synch and conventional protocols), and between cows displaying estrus or not during the J-Synch protocol, were performed by chi-square test, with 95\% confidence interval, considering significant a $P$-value lower than 0.05 . One heifer (Experiment 1) developed a follicular cyst and was excluded from the analysis.

\section{Results and Discussion}

The pregnancy rate was not different $(P=$ 0.68 ) between the conventional and J-Synch protocols (Table 1). Previous studies suggested a tendency for the J-Synch protocol resulting in higher pregnancy rate in heifers compared to the conventional protocol (de la Mata et al., 2015). However, in these studies PGF administration was performed concomitantly with device withdrawal (de la Mata et al., 2015; Menchaca et al., 2015), while in our study PGF was administered 48 hours before device removal in the conventional protocol. A longer time between luteolysis and ovulation can improve fertility due to a prolonged time to corpus luteum regression and lower progesterone concentration at $\mathrm{AI}$; or, alternatively, 
more time to the final follicular growth, increasing

before ovulation (Pereira et al., 2014).

the diameter of the ovulatory follicle and estradiol

Table 1. Pregnancy per artificial insemination according to estrus detection of beef heifers treated with conventional or J-Synch protocol.

Pregnancy per artificial insemination

\begin{tabular}{|c|c|c|c|}
\hline Group & Estrus & No estrus & Overall \\
\hline $\begin{array}{c}\text { Conventional } \\
\text { J-Synch }\end{array}$ & $\begin{array}{c}66.1 \%(41 / 62)^{\mathrm{a}} \\
64.1 \%(25 / 39)\end{array}$ & $\begin{array}{c}39.3 \%(33 / 84)^{\mathrm{bB}} \\
59.1 \%(65 / 110)^{\mathrm{A}}\end{array}$ & $\begin{array}{l}50.7 \%(74 / 146) \\
60.4 \%(90 / 149)\end{array}$ \\
\hline
\end{tabular}

${ }^{\mathrm{a}, \mathrm{b}}$ Different letters in the same line indicate statistical difference between heifers that displayed estrus or not in the same protocol $(\mathrm{P} \leq 0.001)$. ${ }^{\mathrm{A}, \mathrm{B}}$ Different letters in the same column indicate statistical difference between protocols for heifers displaying estrus or not $(\mathrm{P}<0.01)$. $P$ value was calculated by the chi-square test.

Estrus expression was detected in $34.2 \%$ of all synchronized heifers (101/295) and $18.9 \%$ $(22 / 116)$ of the cows. In a study performed by Rivera et al. (2004) $18 \%$ of the dairy heifers demonstrated estrus before the moment of FTAI in a GnRH-based protocol. The proportion of cows with earlier estrus is also superior to previous reports, which vary between 6-9\% (Roy and Twagiramungu, 1996). This higher estrus expression in both heifers and cows could occur due to follicular wave shortening, with females demonstrating estrus closer to the moment of decreased progesterone concentration, resulting in an asynchrony between the moment of ovulation and AI (Rivera et al., 2005). In this way, the association of estrus detection and FTAI protocols could be beneficial to improve pregnancy rates, as observed in our study. A greater number of heifers displaying estrus in the conventional (61.4\%, $62 / 101)$ compared to J-Synch protocol (38.6\%, $39 / 101, P=0.003)$ was observed, in agreement with previous studies (Perry and Perry, 2008; Sa Filho et al., 2011a; Pereira et al., 2013). Administration of ECP can increase pre-ovulatory estradiol concentration, increasing the number of animals in estrus (Perry and Perry, 2008). In addition, earlier PGF administration in the ECP protocol can provide a longer period for follicular development, also increasing estrus expression and follicular size at the moment of AI (Pereira et al., 2014).

The pregnancy rate of heifers displaying estrus was higher than for heifers not displaying estrus in the conventional protocol (Table 1). Previous studies demonstrated that estrus expression in estradiol and GnRH-based FTAI protocols is associated with higher pregnancy rates (Perry et al., 2005; Busch et al., 2007; Busch et al., 2008; Sa Filho et al., 2010). A meta-analysis study showed that females with detected estrus have a $27 \%$ higher pregnancy rate than those not detected as in estrus (Richardson et al., 2016). However, in our study the pregnancy rate was not different between heifers that displayed estrus or not with JSynch protocol (Table 1). The same was observed for cows (displayed estrus: $72.7 \%$, did not display estrus: $54.2 \% ; P=0.15$ ). Additionally, the pregnancy rate was higher in heifers not showing estrus in the J-Synch $(59.1 \%$; 65/110) than in the conventional protocol (39.3\%; 33/84, $P=0.006$ ). These results suggest that the J-Synch protocol results in higher pregnancy rate when used without estrous detection, which is the most common situation in larger farms. This can be due to the more uniform synchronization of ovulation induced by GnRH when compared to longer window of ovulation induced by ECP (Uslenghi et al., 2016). Moreover, estrus expression could be beneficial in protocols that allow a shorter period for proestrus. Some studies suggest that cows exhibiting estrus have larger follicular diameter at AI, increased ovulatory rate, larger corpus luteum, resulting in higher progesterone concentration after AI (Sa Filho et al., 2011b). In protocols with prolonged proestrus, estrus demonstration did not have influence on pregnancy rate (Day, 2015). In these protocols, the use of GnRH results in a $\mathrm{LH}$ pulse release 2 hours after GnRH administration (Chenault et al., 1990). Therefore, there is a higher degree of synchrony between the moment of AI and ovulation. This would be especially beneficial for cows ovulating later, with smaller follicles. Therefore, this suggests that heifers not showing estrus in the J-Synch protocol were assisted by the use of GnRH in this protocol, having a higher pregnancy rate than heifers not showing estrus in the conventional protocol and a similar pregnancy rate to heifers showing estrus in the same protocol. 


\section{Conclusion}

The hastening of the AI moment according to estrus expression increases the pregnancy rate of heifers in the conventional protocol; however, it is not beneficial in heifers and cows synchronized with the J-Synch protocol. The J-Synch protocol did not improved pregnancy rate when compared to the conventional protocol in heifers.

\section{Conflict of interests}

None of the authors of this study has any conflict of interest.

\section{Ethics Committee}

The Committee for Ethics in Animal Experimentation of the Federal University of Pelotas (UFPel) approved all procedures performed in this experiment (Protocol 23110.005324/2017-49).

\section{Acknowledgements}

To Coordenação de Aperfeiçoamento de Pessoal de Nível Superior (CAPES) for financial support.

\section{References}

Bó, G.A.; Adams, G.P.; Pierson, R.A.; Tríbulo, H.; Caccia, M.; Mapletoft, R.J. Follicular wave dynamics after estradiol-17 $\beta$ treatment of heifers with or without a progestogen implant. Theriogenology, 41: 1555-1569, 1994.

Bridges, G.A.; Helser, L.A.; Grum, D.E.; Mussard, M.L.; Gasser, C.L.; Day, M.L. Decreasing the interval between GnRH and PGF2alpha from 7 to 5 days and lengthening proestrus increases timed-ai pregnancy rates in beef cows. Theriogenology, 69: 843-851, 2008.

Bridges, G.A.; Mussard, M.L.; Burke, C.R.; Day, M.L. Influence of the length of proestrus on fertility and endocrine function in female cattle. Animal Reproduction Science, 117: 208-215, 2010.

Busch, D.C.; Schafer, D.J.; Wilson, D.J.; Mallory, D.A.; Leitman, N.R.; Haden, J.K.; Ellersieck, M.R.; Smith, M.F.; Patterson, D.J. Timing of artificial insemination in postpartum beef cows following administration of the co-synch + controlled internal drug release protocol. Journal of Animal Science, 86: 1519-1525, 2008.

Busch, D.C.; Wilson, D.J.; Schafer, D.J.; Leitman, N.R.; Haden, J.K.; Ellersieck, M.R.; Smith, M.F.; Patterson, D.J. Comparison of progestin-based estrus synchronization protocols before fixed-time artificial insemination on pregnancy rate in beef heifers. Journal of Animal Science, 85: 1933-1939, 2007.

Cavalieri, J.; Hepworth, G.; Macmillan, K.L. Ovarian follicular development in holstein cows following synchronization of oestrus with oestradiol benzoate and an intravaginal progesterone releasing insert 5-9 days and duration of the oestrus cycle and concentrations of progesterone following ovulation. Animal Reproduction Science, 81: 177-193, 2004.

Cerri, R.L.; Rutigliano, H.M.; Chebel, R.C.; Santos, J.E. Period of dominance of the ovulatory follicle influences embryo quality in lactating dairy cows. Reproduction, 137: 813-823, 2009.

Chenault, J.R.; Kratzer, D.D.; Rzepkowski, R. A.; Goodwin, M.C. LH and FSH response of Holstein heifers to fertirelin acetate, gonadorelin and buserelin. Theriogenology, 34: 81-98, 1990.

Dadarwal, D.; Mapletoft, R.J.; Adams, G.P.; Pfeifer, L.F.; Creelman, C.; Singh, J. Effect of progesterone concentration and duration of proestrus on fertility in beef cattle after fixedtime artificial insemination. Theriogenology, 158: 96-103, 2013.

Day, M.L. State of the art of GnRH-based time ai in beef cattle. Animal Reproduction, 12: 473-478, 2015.

De La Mata, J.J.; Bó, G. A. Estrus synchronization and ovulation using protocols with estradiol benzoate and GnRH and reduced periods of a insertion of a progesterone releasing device in beef heifers. Revista Taurus, 55: 17-23, 2012.

De La Mata, J.J.; Ré, M.; Bó, G.A. Combination of estrus detection and fixed-timed artificial insemination in beef heifers following shortened estradiol-based that provides for a lengthened proestrus. Reproduction, fertility and development, 27: 96, 2015.

Houghton, P.L.; Lemenager, R.P.; Hendrix, K.S.; Moss, G.E.; Stewart, T.S. Effects of body composition, pre- and postpartum energy intake and stage of production of energy utilization by beef cows. Journal of Animal Science, 68: 1447-1456, 1990.

Mapletoft, R.J.; Martinez, M.F.; Colazo, M.G.; Kastelic, J.P. The use of controlled internal 
drug release devices for the regulation of bovine reproduction. Journal Animal Science, 81(2): 28-36, 2003.

Menchaca, A.; Cuadro, F.; Nuñes, R.; Bó, G.A. Pregnancy rates in beef heifers synchronized with shortened estradiol-based treatment that provides for a prolonged proestrus. Reproduction, fertility and development, 27: 96, 2015.

Pereira, M.H.; Rodrigues, A.D.; de Carvalho, R.J.; Wiltbank, M.C.; Vasconcelos, J.L. Increasing length of an estradiol and progesterone timed artificial insemination protocol decreases pregnancy losses in lactating dairy cows. Journal of Dairy science, 97: 1454-1464, 2014.

Pereira, M.H.; Rodrigues, A.D.; Martins. T.; Oliveira, W.V.; Silveira, P.S.; Wiltbank, M.C.; Vasconcelos, J.L. Timed artificial insemination programs during the summer in lactating dairy cows: comparison of the 5-d Cosynch protocol with an estrogen/progesterone-based protocol. Journal of Dairy Science, 96: 6904-6914, 2013.

Perry, G.A.; Perry, B.L. Effect of preovulatory concentrations of estradiol and initiation of standing estrus on uterine $\mathrm{pH}$ in beef cows. Domestic Animal Endocrinology, 34: 333338, 2008.

Perry, G.A.; Smith, M.F.; Lucy, M.C.; Green, J.A.; Parks, T.E.; Macneil, M.D.; Roberts, A.J.; Geary, T.W. Relationship between follicle size at insemination and pregnancy success. Proceedings of the National Academy of Sciences of the United States of America, 102: 5268-5273, 2005.

Richardson, B.N.; Hill, S.C.; Stevenson, J.S.; Djira, G.D.; Perry, G.A. Expression of estrus before fixed-time AI affects conception rates and factors that impact expression of estrus and the repeatability of expression of estrus in sequential breeding seasons. Animal Reproduction Science, 166: 133-140, 2016.

Rivera, H., Lopes, H., Fricke, P.M. Use of intravaginal progesterone-releasing inserts in a synchronization protocol before timed AI and for synchronization return to estrus in holstein heifers. Journal of Dairy Science, 88: 957-968, 2005.

Roy, G.L.; Twagiramungu, H. A fixed-time AI program using the GnRH-PGF2 $\alpha-G n R H$ method for beef females. Journal Animal Science, 74: 462, 1996.

Sa Filho, M.F.; Baldrighi, J.M.; Sales, J.N.; Crepaldi, G.A.; Carvalho, J.B.; Bo, G.A.; Baruselli, P.S. Induction of ovarian follicular wave emergence and ovulation in progestinbased timed artificial insemination protocols for Bos indicus cattle. Animal Reproduction Science, 129: 132-139, 2011a.

Sa Filho, M.F.; Crespilho, A.M.; Santos, J.E.; Perry, G.A.; Barusseli, P.S. Ovarian follicle diameter at timed insemination and estrous response influence likelihood of ovulation and pregnancy after estrous synchronization with progesterone or progestin-based protocols in suckled Bos indicus cows. Animal Reproduction Science, 120: 23-30, 2010.

Sa filho, M.F.; Santos, J.E.; Ferreira, R.M.; Sales, J.N.; Baruselli, P.S. Importance of estrus on pregnancy per insemination in suckled Bos indicus cows submitted to estradiol/progesterone-based timed insemination protocols. Theriogenology, 76: 455-463, $2011 \mathrm{~b}$.

Uslenghi, G.; Vater, A.; Rodriguez Aguilar, S.; Cabodevila, J.; Callejas, S. Effect of estradiol cypionate and GnRH treatment on plasma estraiol-17beta concentrations, synchronization of ovulation and on pregnancy rates in suckled beef cows treated with FTAI-based protocols. Reproduction in Domestic Animals, 51: 693-699, 2016. 